\title{
Top Management Support, Organizational Learning, Innovative Behavior, Employee Commitment and Organizational Performance of Manufacturing Companies in Hai Phong
}

\author{
Tuyen Khac Pham ${ }^{1}$, Cuong Hung Pham ${ }^{2} \&$ Long Pham ${ }^{3}$ \\ ${ }^{1}$ Hai Phong City Inspection Committee of the Party, Vietnam \\ ${ }^{2}$ Foreign Trade University, Ho Chi Minh City Campus, Vietnam \\ ${ }^{3}$ National Economics University, Vietnam \\ Correspondence: Cuong Hung Pham, Foreign Trade University, Ho Chi Minh City Campus, \#15D5, Ward 25, Binh \\ Thanh District, Ho Chi Minh City, Vietnam.
}

Received: April 10, 2016

doi:10.5430/ijfr.v7n3p54
Accepted: May 4, 2016

Online Published: May 13, 2016

URL: http://dx.doi.org/10.5430/ijfr.v7n3p54

\begin{abstract}
Many organizational researchers consider innovative behavior to be an important work related factor (Fex \& Spector, 2006). Researchers have found strong links between innovative behavior and organizational performance in the workplace. Jex, Beehr and Roberts (1992) found innovative behavior of employees as direct outcomes of organizational performance. Similarly, innovative behavior has been identified as a major effect for financial outcomes by many researchers (Dewe, 2003). Innovative behavior was found to be another major effect for employee satisfaction (Fox and Spector, 2006). Fox and Spector (2006) identified positive work behavior as a behavioral response caused by innovative behavior of employees (Noe, 2000). Top management support is another highly researched organizational factor that has been found to affect job attitudes and work behavior (Weiss, 2002). Top management support has been found to affect behaviors such as organizational citizenship behavior, absenteeism, turnover, and work performance (Feather \& Rauter, 2004). In a HRD related topic, Egan, Yang and Barlett (2004) examined the relationship between top management support and organizational performance and shown that there is a positive relationship between these two variables. The factors discussed above that is organizational learning, top management support, innovative behavior, employee commitment, and organizational performance are the focus of this study. Exploration of these variables was based on a systematic examination of literature, a unique contribution toward elaborating upon the elements impacting organizational performance.
\end{abstract}

Keywords: top management support, organizational learning, innovative behavior, employee commitment, organizational performance, manufacturing companies, Hai Phong

\section{Introduction}

Two organizational factors are the focus of the current study, top management support and employee commitment. In transfer research, while employee commitment has received some attention (Egan et al., 2004), innovative behavior appears to have received attention at all. The potential effects of top management support on organizational performance have already been highlighted. Top management support has been found to affect several work attitudes and behaviors, and has been a major focus area among organizational researchers (Jonge \& Lanbergis, 2005). Ganster and Schaubroeck (1991), in a review of ten years of the top management support literature, found more than 300 published articles. No published study examining the influence of top management support and organizational learning on employee commitment and performance was identified. Similarly job satisfaction and its effect on organizational learning have not been sufficiently examined. In addressing the issues identified so far, first, organizational learning researchers need to continue to focus on some of the key situational and individual factors that could potentially influence organizational performance. The objective of the current study was not only to measure important factors that affect organizational performance but also to limit the number of factors and items of measurement in order to keep the overall instrument within an acceptable length. According to Cox (1996), in typical contexts and for optimal results, a survey should not take more than ten to twelve minutes to finish. Thus the length 
of the instrument was a key consideration in choosing item sets for this study. In the current study a survey to measure key factors impacting on organizational performance was used.

\section{Literature Review}

Top Management Support. Treatment in the literature for TMS is ambiguous and does not agree on a common view of the concept (Dong et al., 2009). The majority argues that TMS is a set of resultant actions arising from the behavior of top managers (Manfreda \& Stemberger, 2014). Other argue for managerial perceptions (Leonard-Barton \& Deschamps, 1998). Some even argue for both (Basellier \& Pinsonneault, 1998), but have failed to attract many followers. This decision further adds to the confusion on the state of the concept. Hence, it becomes obvious that the concept has rarely been studied in adequate depth ( Butler \& Fitzgerald, 1999). The literature specifies that when top managers extend support, there is a high possibility of achieving better performance at organizational levels (Williams \& Ramaprasad, 1996). This study refers across these levels with the intent of understanding the treatment in the literature on the concept of behaviour based TMS. The most logical reason for behaviour based TMS to be more popular is the possibility of observing and reporting the actions, either by the top management or the project who are in need of supportive actions. TMS definitions cover a large number of activities that are carried out by the top management. These activities no doubt help improve organizational performance. However, these definitions have not employed theoretical or empirical rigour when compiling definitions. Hence, many researchers tend to initiate and follow many different notions regarding TMS (Dong et al., 2009). Academics are criticized for uncritically accepting theoretical concepts (Donaldson \& Preston, 1995). The implication of working with ill-defined concepts is usually unreliable research outcome, as "concepts are the building blocks of science upon which propositions are based" (Osigweh, 1989).

Innovative Behavior. Cognitive psychology (Neisser, 1967) help explain the mental processes by which individual interact with other people and the embedded environment. Social cognition theory (Fiske \& Taylor, 1984) has been developed to specifically explain the individual behavior in this person-environment interaction. This theory introduces the idea of knowledge structures: mental models are ordered in such a way as to optimize personal effectiveness within given situation. In this dissertation, cognitions are defined as the managers' or entrepreneurs' mental reflections of a certain phenomenon, namely, the process of innovation. Cognitive studies explore the cognitive processes that lie behind strategic choices. As a complement of the theory of rational choice, cognitive science has attempted to explain why or how economic decisions happen in an uncertain and subjective world (Kahneman, Slovic, \& Tversky, 1982; Simon, 1957; Smircich \& Stubbart, 1985). As thinking drives strategy-making, managerial cognition resides at the core of the strategic management process (Stubbart, 1989). Managers take strategic action intentionally to respond to the changing environment. Managerial cognitive structures shape firm strategies for growth because the management team's conceptualization and employment of the firm's resource base influence the direction of expansion. Managers pursue competitive actions and deploy resources in a way that is consistent with their mental models of the firm's capabilities and with the competitive threats that they believe it faces. The determinants of the growth and direction of a firm are the productive capabilities that are engendered by resources interacting with managerial cognitive frameworks instead of the actual resources themselves (Porac, Thomas, Wilson, Paton \& Kanfer, 1995).

Organizational Performance. This section discusses the notions of organizational performance in the literature. Organizational performance is considered the dependent variable. It is shown that TMS affects the outcome of organizations. Hence, in order to proceed with the thesis, it is next necessary to illustrate how different notions were considered when selecting the most appropriate organizational performance or the dependent variable. In general, the literature identifies two popular notions when discussing the organizational performance (Savolainen et al., 2012). The first group indentifies achieving the goals as success (Agarwal \& Rathoder, 2006) while the second group indentifies this as organizational performance (Barclay, 2008). It is difficult to determine if one notion is preferred above the other, as some refer to these terms interchangeably (Gemino et al., 2007). Few others say that positive organizational performance will lead to success (Hong, 2011), others do not report a direct connection (Turnern \& Muller, 2004). For the purpose of this research, both success and organizational performance notions were looked at in some detail.

Both success and organizational performance are report as multi-dimensional, some of which are similar across performance and success notions. Organizational performance descriptions in the literature are usually segregated into two dimensions following which further sub-dimensions are indentified. "Organizational performance, which describes how well the development process has been undertaken" (Nidumolu, 1995) and the "product performance, which describes the performance of the system actually delivered to users" are two main dimensions (Nidumolu, 
1995). The concept of success was the first to appear in the literature and scholars claim that the first initiatives towards a definition of success were seen in the 1970's (Davis, 2014) and early 1980's (Muller \& Jugdev, 2012). Organizational performance was a phenomenon that followed, possibly as a progression of the early knowledge. When considering both organizational performance and success notions on outcome, most agree that an organization has to meet the requirements about time, cost and scope. Other researchers have added more dimensions to supplement these. Most studies still include the requirements as part of success.

\section{Research Method}

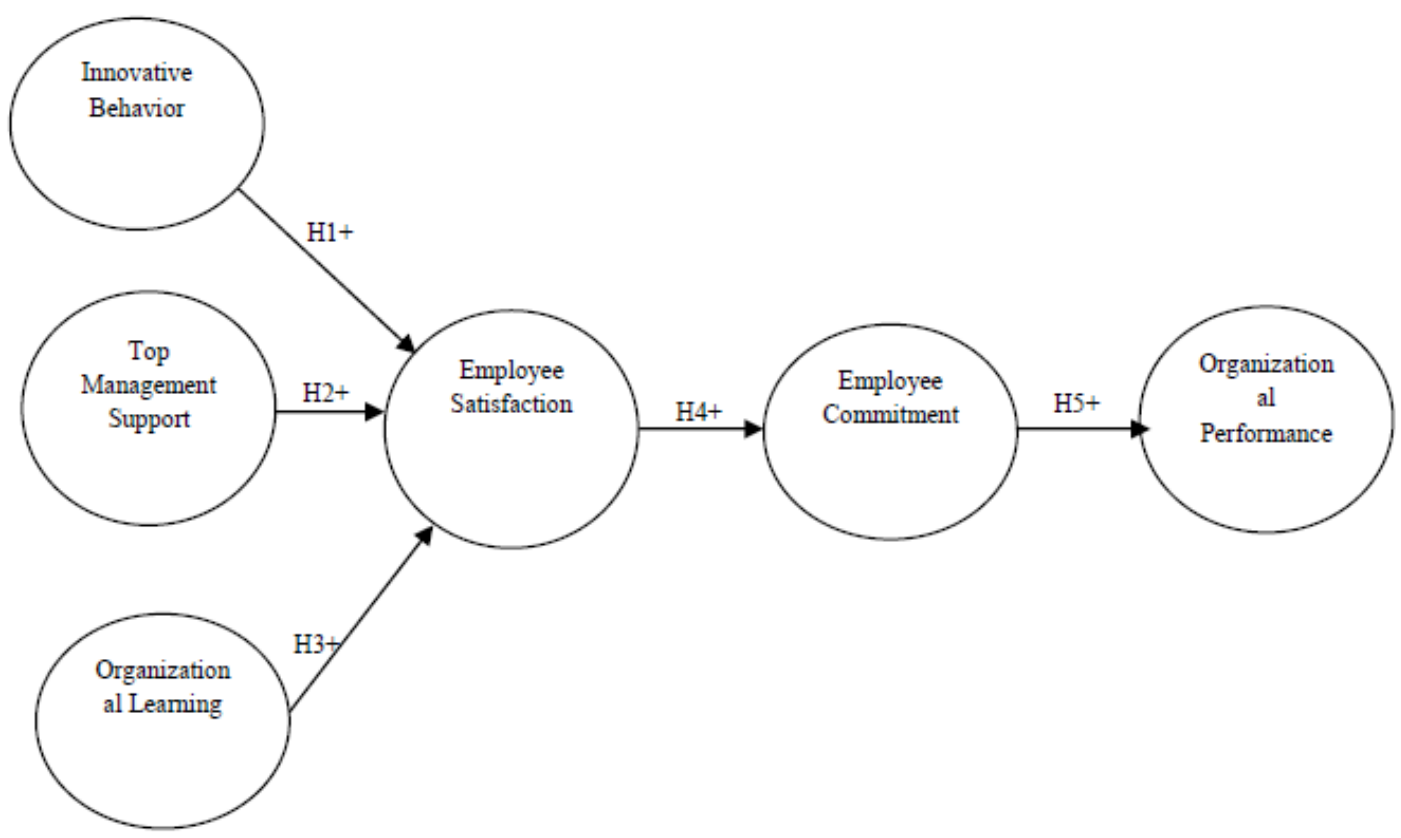

Figure 1. Research model

The research hypotheses can be integrated to form a set of structural equations. The following abbreviations are used for simplicity: innovative behavior (IB), top management support (TMP), organizational learning (OL), employee satisfaction (ES), employee commitment (EC), and organizational performance (OP). So, the structural model can be represented as:

$$
\begin{gathered}
\mathrm{ES}=\mathrm{\gamma}_{1}(\mathrm{IB})+\gamma_{2}(\mathrm{TMS})+\gamma_{3}(\mathrm{OL})+\zeta_{1} \\
\mathrm{EC}=\gamma_{4}(\mathrm{ES})+\zeta_{2} \\
\mathrm{OP}=\gamma_{5}(\mathrm{EC})+\zeta_{3}
\end{gathered}
$$

H1: There is a positive relationship between innovative behavior and employee satisfaction

$\mathrm{H} 2$ : There is a positive relationship between top management support and employee satisfaction

H3: There is a positive relationship between organizational learning and employee satisfaction

H4: There is a positive relationship between employee satisfaction and employee commitment

H5: There is a positive relationship between employee commitment and organizational performance

\section{Research Results}

Regarding revenues, it is recognized that the revenue the revenue of the surveyed organizations was reasonable stable from the year 2012 - 2014. In the total sample, about $37 \%$ of organizations had VND 11-100 billion in revenue, nearly $30 \%$ had VND $101-500$ billion, about 17\% had less than VND 10 billion, and remaining organizations had more than VND 500 billion.

We implemented an extensive review of the literature and initially adopted many of the scales validated in the literature. These pilot scales were reviewed by four managers who had been involved in strategy initiatives in their companies, and five academicians, whose expertise is in organizational behavior. Several revisions were made based 
on the experts' comments/feedback. A brief version of the survey instruments is provided in Appendix. As shown, the questionnaire consists of 21 items. Among the 21 items, 4 items are designed to measure Innovative Behavior; 3 items for Top Management Support; 5 items for Organizational Learning; 2 items for Employee Satisfaction; 4 items for Employee Commitment, and 3 items for Organizational Performance. In this survey, each survey respondent was asked to rate his or her perception of and experience on a seven-point Likert scale.

A Vietnamese scholar translated the final version of the questionnaire into Vietnamese. Another researcher, who is fluent in both Vietnamese and English, translated the Vietnamese version back into English to ensure consistency between the English and Vietnamese versions. Then, two scholars who are Vietnamese-English bilingual examined both the Vietnamese and the English versions independently and validated that the translation was accurate and consistent. This revised questionnaire was pre-tested and the scale items were further refined based on their comments and suggestions.

In this study, we attempted to identify a group of factors that would lead to organizational performance by companies in Hai Phong. In order to collect data from companies in Hai Phong, 600 questionnaires were sent out. Each company received 5 questionnaires. There were a total of 120 companies. Among 600 questionnaires sent out, 511 questionnaires were returned and usable, resulting in a response rate of $85.17 \%$.

Table 1 . The results of reliability analysis for the construct innovative behavior

\begin{tabular}{cccccc}
\hline & $\begin{array}{c}\text { Scale Mean if } \\
\text { Item Deleted }\end{array}$ & $\begin{array}{c}\text { Scale Variance } \\
\text { if Item Deleted }\end{array}$ & $\begin{array}{c}\text { Corrected } \\
\text { Item-Total } \\
\text { Correlation }\end{array}$ & $\begin{array}{c}\text { Squared } \\
\text { Multiple } \\
\text { Correlation }\end{array}$ & $\begin{array}{c}\text { Cronbach's } \\
\text { Alpha if Item } \\
\text { Deleted }\end{array}$ \\
\hline IB_1 & 14.99 & 10.313 & .652 & .452 & .861 \\
IB_2 & 14.68 & 9.727 & .742 & .553 & .827 \\
IB_3 & 14.78 & 8.941 & .733 & .585 & .832 \\
IB_4 & 15.02 & 9.333 & .774 & .612 & .814 \\
\hline
\end{tabular}

It should be noted that Cronbach's alpha for Innovative Behavior is 0.87 , and Cronbach's alpha if each item of the construct deleted is less than 0.87 . Thus, the reliability of this construct is very high $(0.87>0.7)$ and all the 4 items are remained for further analysis.

Table 2 . The results of reliability analysis for the construct top management support

\begin{tabular}{lccccc}
\hline & $\begin{array}{c}\text { Scale Mean if } \\
\text { Item Deleted }\end{array}$ & $\begin{array}{c}\text { Scale Variance } \\
\text { if Item Deleted }\end{array}$ & $\begin{array}{c}\text { Corrected } \\
\text { Item-Total } \\
\text { Correlation }\end{array}$ & $\begin{array}{c}\text { Squared } \\
\text { Multiple } \\
\text { Correlation }\end{array}$ & $\begin{array}{c}\text { Cronbach's } \\
\text { Alpha if Item } \\
\text { Deleted }\end{array}$ \\
\hline TMS_1 & 10.33 & 4.205 & .719 & .518 & .809 \\
TMS_2 & 10.10 & 3.458 & .746 & .557 & .778 \\
TMS_3 & 10.21 & 3.641 & .724 & .525 & .797 \\
\hline
\end{tabular}

It should be noted that Cronbach's alpha for Top Management Support is 0.854, and Cronbach's alpha if each item of the construct deleted is less than 0.854 . Thus, the reliability of this construct is very high $(0.854>0.7)$ and all the 3 items are remained for further analysis.

Table 3. The results of reliability analysis for the construct organizational learning

\begin{tabular}{lrrrrr}
\hline & $\begin{array}{c}\text { Scale Mean if } \\
\text { Item Deleted }\end{array}$ & $\begin{array}{c}\text { Scale Variance } \\
\text { if Item Deleted }\end{array}$ & $\begin{array}{c}\text { Corrected } \\
\text { Item-Total } \\
\text { Correlation }\end{array}$ & $\begin{array}{c}\text { Squared } \\
\text { Multiple } \\
\text { Correlation }\end{array}$ & $\begin{array}{c}\text { Cronbach's } \\
\text { Alpha if Item } \\
\text { Deleted }\end{array}$ \\
\hline OL_1 & 19.63 & 19.496 & .750 & .589 & .863 \\
OL_2 & 19.54 & 19.724 & .764 & .626 & .860 \\
OL_3 & 19.66 & 19.555 & .784 & .620 & .855 \\
OL_4 & 19.48 & 20.093 & .766 & .599 & .860 \\
OL_5 & 19.79 & 19.834 & .622 & .403 & .895 \\
\hline
\end{tabular}


It should be noted that Cronbach's alpha for Organizational Learning is 0.896 , and Cronbach's alpha if each item of the construct deleted is less than 0.896 . Thus, the reliability of this construct is very high $(0.896>0.7)$ and all the 5 items are remained for further analysis.

Table 4 . The results of reliability analysis for the construct employee satisfaction

\begin{tabular}{lcrrrr}
\hline & $\begin{array}{c}\text { Scale Mean if } \\
\text { Item Deleted }\end{array}$ & $\begin{array}{c}\text { Scale Variance } \\
\text { if Item Deleted }\end{array}$ & $\begin{array}{c}\text { Corrected } \\
\text { Item-Total } \\
\text { Correlation }\end{array}$ & $\begin{array}{c}\text { Squared } \\
\text { Multiple } \\
\text { Correlation }\end{array}$ & $\begin{array}{c}\text { Cronbach's } \\
\text { Alpha if Item } \\
\text { Deleted }\end{array}$ \\
\hline ES_1 & 5.04 & 1.461 & .748 & .560 & \\
ES_2 & 5.15 & 1.433 & .748 & .560 &. \\
\hline
\end{tabular}

It should be noted that Cronbach's alpha for Employee Satisfaction is 0.856, and Cronbach's alpha if each item of the construct deleted is less than 0.856 . Thus, the reliability of this construct is very high $(0.856>0.7)$ and all the 2 items are remained for further analysis.

Table 5. The results of reliability analysis for the construct employee commitment

\begin{tabular}{lrrrrr}
\hline & $\begin{array}{c}\text { Scale Mean if } \\
\text { Item Deleted }\end{array}$ & $\begin{array}{c}\text { Scale Variance } \\
\text { if Item Deleted }\end{array}$ & $\begin{array}{c}\text { Corrected } \\
\text { Item-Total } \\
\text { Correlation }\end{array}$ & $\begin{array}{c}\text { Squared } \\
\text { Multiple } \\
\text { Correlation }\end{array}$ & $\begin{array}{c}\text { Cronbach's } \\
\text { Alpha if Item } \\
\text { Deleted }\end{array}$ \\
\hline EC_1 & 15.39 & 10.290 & .802 & .659 & .878 \\
EC_2 & 15.37 & 10.311 & .800 & .652 & .879 \\
EC_3 & 15.38 & 10.354 & .795 & .637 & .880 \\
EC_4 & 15.35 & 10.282 & .773 & .607 & .888 \\
\hline
\end{tabular}

It should be noted that Cronbach's alpha for Employee Commitment is 0.908, and Cronbach's alpha if each item of the construct deleted is less than 0.908 . Thus, the reliability of this construct is very high $(0.908>0.7)$ and all the 4 items are remained for further analysis.

Table 6 . The results of reliability analysis for the construct organizational performance

\begin{tabular}{lcrrrr}
\hline & $\begin{array}{c}\text { Scale Mean if } \\
\text { Item Deleted }\end{array}$ & $\begin{array}{c}\text { Scale Variance } \\
\text { if Item Deleted }\end{array}$ & $\begin{array}{c}\text { Corrected } \\
\text { Item-Total } \\
\text { Correlation }\end{array}$ & $\begin{array}{c}\text { Squared } \\
\text { Multiple } \\
\text { Correlation }\end{array}$ & $\begin{array}{c}\text { Cronbach's } \\
\text { Alpha if Item } \\
\text { Deleted }\end{array}$ \\
\hline OP_1 & 10.20 & 5.825 & .697 & .486 & .800 \\
OP_2 & 10.48 & 5.348 & .713 & .509 & .782 \\
OP_3 & 10.44 & 5.047 & .729 & .532 & .768 \\
\hline
\end{tabular}

It should be noted that Cronbach's alpha for Organizational Performance is 0.845, and Cronbach's alpha if each item of the construct deleted is less than 0.845 . Thus, the reliability of this construct is very high $(0.845>0.7)$ and all the 3 items are remained for further analysis.

\subsection{Results from Testing the Structural Model}

Using Mplus to test the structural model with the following codes:

$$
\begin{aligned}
& \text { variable: names are IB_1 } \mathrm{IB} \_2 \mathrm{IB} \_3 \mathrm{IB} \_4 \\
& \\
& \text { TMS_1 TMS_2 TMS_3 } \\
& \text { OL_1 OL_2 OL_3 OL_4 OL_5 } \\
& \text { ES_1 ES_2 } \\
& \text { EC_1 EC_2 EC_3 EC_4 } \\
& \text { OP_1 OP_2 OP_3; }
\end{aligned}
$$

model: f1 by IB_1@1 IB_2 IB_3 IB_4;

f2 by TMS_1@1 TMS_2 TMS_3; 


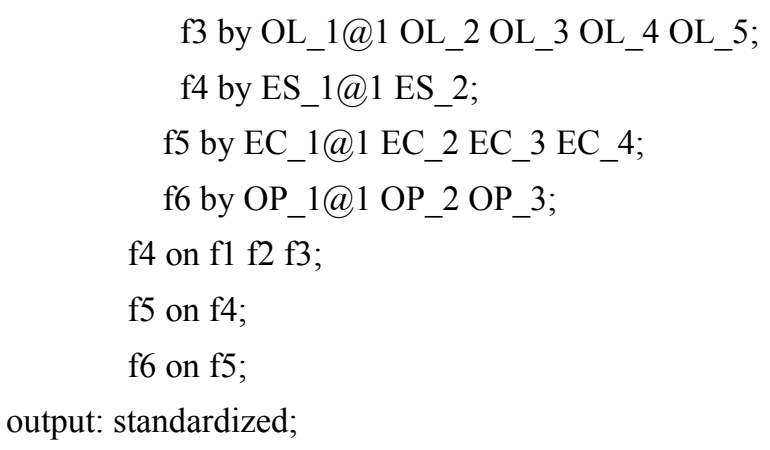

The following are the results:

Number of Free Parameters

Loglikelihood

$\begin{array}{ll}\text { H0 Value } & -13228.985 \\ \text { H1 Value } & -12919.946\end{array}$

Information Criteria

$\begin{array}{lc}\text { Akaike (AIC) } & 26599.971 \\ \text { Bayesian (BIC) } & 26900.753 \\ \text { Sample-Size Adjusted BIC } & 26675.389\end{array}$

$\left(n^{*}=(n+2) / 24\right)$

Chi-Square Test of Model Fit

Value $\quad 618.078$

Degrees of Freedom $\quad 181$

P-Value $\quad 0.0000$

RMSEA (Root Mean Square Error Of Approximation)

Estimate $\quad 0.069$

90 Percent C.I. $\quad 0.063 \quad 0.075$

Probability RMSEA $<=.05 \quad 0.000$

CFI/TLI

$\begin{array}{ll}\text { CFI } & 0.948\end{array}$

TLI 0.940

Chi-Square Test of Model Fit for the Baseline Model

$\begin{array}{lc}\text { Value } & 8689.220 \\ \text { Degrees of Freedom } & 210 \\ \text { P-Value } & 0.0000\end{array}$

SRMR (Standardized Root Mean Square Residual)

Value

0.037

STANDARDIZED MODEL RESULTS

STDYX Standardization

Two-Tailed 


\begin{tabular}{|c|c|c|c|c|c|}
\hline & & Estimate & S.E. & Est./S.E. & P-Value \\
\hline $\mathrm{F} 1$ & BY & & & & \\
\hline IB_1 & & 0.712 & 0.024 & 29.624 & 0.000 \\
\hline IB_2 & & 0.824 & 0.017 & 48.169 & 0.000 \\
\hline IB_3 & & 0.788 & 0.020 & 40.352 & 0.000 \\
\hline IB_4 & & 0.847 & 0.016 & 54.074 & 0.000 \\
\hline $\mathrm{F} 2$ & BY & & & & \\
\hline TMS_1 & & 0.847 & 0.015 & 56.104 & 0.000 \\
\hline TMS_2 & & 0.794 & 0.019 & 41.762 & 0.000 \\
\hline TMS_3 & & 0.799 & 0.018 & 43.478 & 0.000 \\
\hline F3 & BY & & & & \\
\hline OL_1 & & 0.805 & 0.018 & 44.984 & 0.000 \\
\hline $\mathrm{OL} \_2$ & & 0.829 & 0.016 & 50.973 & 0.000 \\
\hline $\mathrm{OL} \_3$ & & 0.837 & 0.016 & 53.407 & 0.000 \\
\hline $\mathrm{OL} \_4$ & & 0.822 & 0.017 & 49.146 & 0.000 \\
\hline OL_5 & & 0.676 & 0.026 & 25.892 & 0.000 \\
\hline $\mathrm{F} 4$ & BY & & & & \\
\hline ES_1 & & 0.829 & 0.016 & 51.341 & 0.000 \\
\hline ES_2 & & 0.854 & 0.015 & 58.578 & 0.000 \\
\hline F5 & BY & & & & \\
\hline EC_1 & & 0.861 & 0.013 & 64.032 & 0.000 \\
\hline EC_2 & & 0.841 & 0.015 & 56.774 & 0.000 \\
\hline EC_3 & & 0.838 & 0.015 & 55.676 & 0.000 \\
\hline EC_4 & & 0.823 & 0.016 & 51.071 & 0.000 \\
\hline F6 & BY & & & & \\
\hline OP_1 & & 0.812 & 0.019 & 42.417 & 0.000 \\
\hline OP_2 & & 0.804 & 0.020 & 40.915 & 0.000 \\
\hline OP_3 & & 0.794 & 0.020 & 38.996 & 0.000 \\
\hline $\mathrm{F} 4$ & ON & & & & \\
\hline $\mathrm{F} 1$ & & -0.030 & 0.161 & -0.187 & 0.852 \\
\hline F2 & & 0.537 & 0.187 & 2.876 & 0.004 \\
\hline F3 & & 0.469 & 0.058 & 8.036 & 0.000 \\
\hline F5 & ON & & & & \\
\hline F4 & & 0.929 & 0.011 & 80.799 & 0.000 \\
\hline F6 & ON & & & & \\
\hline F5 & & 0.879 & 0.017 & 51.426 & 0.000 \\
\hline $\mathrm{F} 2$ & WITH & & & & \\
\hline F1 & & 0.946 & 0.014 & 68.211 & 0.000 \\
\hline $\mathrm{F} 3$ & WITH & & & & \\
\hline $\mathrm{F} 1$ & & 0.758 & 0.025 & 30.628 & 0.000 \\
\hline F2 & & 0.817 & 0.022 & 37.577 & 0.000 \\
\hline
\end{tabular}




\begin{tabular}{|c|c|c|c|c|}
\hline \multicolumn{5}{|l|}{ Intercepts } \\
\hline IB_1 & 4.278 & 0.141 & 30.353 & 0.000 \\
\hline IB_2 & 4.506 & 0.148 & 30.502 & 0.000 \\
\hline IB_3 & 3.889 & 0.129 & 30.044 & 0.000 \\
\hline IB_4 & 4.063 & 0.135 & 30.192 & 0.000 \\
\hline TMS_1 & 5.266 & 0.171 & 30.875 & 0.000 \\
\hline TMS_2 & 4.603 & 0.151 & 30.559 & 0.000 \\
\hline TMS_3 & 4.640 & 0.152 & 30.580 & 0.000 \\
\hline OL_1 & 3.697 & 0.124 & 29.858 & 0.000 \\
\hline $\mathrm{OL} \_2$ & 3.909 & 0.130 & 30.062 & 0.000 \\
\hline OL_3 & 3.821 & 0.127 & 29.981 & 0.000 \\
\hline $\mathrm{OL} \_4$ & 4.120 & 0.136 & 30.237 & 0.000 \\
\hline OL_5 & 3.252 & 0.111 & 29.317 & 0.000 \\
\hline ES_1 & 4.306 & 0.142 & 30.372 & 0.000 \\
\hline ES_2 & 4.173 & 0.138 & 30.277 & 0.000 \\
\hline EC_1 & 4.314 & 0.142 & 30.378 & 0.000 \\
\hline EC_2 & 4.341 & 0.143 & 30.396 & 0.000 \\
\hline EC_3 & 4.339 & 0.143 & 30.395 & 0.000 \\
\hline EC_4 & 4.242 & 0.140 & 30.328 & 0.000 \\
\hline OP_1 & 4.478 & 0.147 & 30.485 & 0.000 \\
\hline OP_2 & 3.930 & 0.131 & 30.081 & 0.000 \\
\hline $\mathrm{OP} \_3$ & 3.799 & 0.127 & 29.960 & 0.000 \\
\hline \multicolumn{5}{|l|}{ Variances } \\
\hline F1 & 1.000 & 0.000 & 999.000 & 999.000 \\
\hline $\mathrm{F} 2$ & 1.000 & 0.000 & 999.000 & 999.000 \\
\hline $\mathrm{F} 3$ & 1.000 & 0.000 & 999.000 & 999.000 \\
\hline \multicolumn{5}{|c|}{ Residual Variances } \\
\hline IB_1 & 0.493 & 0.034 & 14.380 & 0.000 \\
\hline IB_2 & 0.322 & 0.028 & 11.415 & 0.000 \\
\hline IB_3 & 0.380 & 0.031 & 12.341 & 0.000 \\
\hline IB_4 & 0.283 & 0.027 & 10.661 & 0.000 \\
\hline TMS_1 & 0.283 & 0.026 & 11.093 & 0.000 \\
\hline TMS_2 & 0.369 & 0.030 & 12.202 & 0.000 \\
\hline TMS_3 & 0.361 & 0.029 & 12.307 & 0.000 \\
\hline OL_1 & 0.352 & 0.029 & 12.205 & 0.000 \\
\hline $\mathrm{OL} \_2$ & 0.312 & 0.027 & 11.576 & 0.000 \\
\hline $\mathrm{OL} \_3$ & 0.299 & 0.026 & 11.374 & 0.000 \\
\hline OL_4 & 0.325 & 0.027 & 11.815 & 0.000 \\
\hline OL_5 & 0.543 & 0.035 & 15.407 & 0.000 \\
\hline ES_1 & 0.312 & 0.027 & 11.656 & 0.000 \\
\hline ES 2 & 0.271 & 0.025 & 10.874 & 0.000 \\
\hline
\end{tabular}




$\begin{array}{lllll}\text { EC_1 } & 0.259 & 0.023 & 11.188 & 0.000 \\ \text { EC_2 } & 0.292 & 0.025 & 11.736 & 0.000 \\ \text { EC_3 } & 0.298 & 0.025 & 11.820 & 0.000 \\ \text { EC_4 } & 0.323 & 0.027 & 12.186 & 0.000 \\ \text { OP_1 } & 0.341 & 0.031 & 10.965 & 0.000 \\ \text { OP_2 } & 0.353 & 0.032 & 11.151 & 0.000 \\ \text { OP_3 } & 0.370 & 0.032 & 11.433 & 0.000 \\ \text { F4 } & 0.132 & 0.021 & 6.217 & 0.000 \\ \text { F5 } & 0.138 & 0.021 & 6.443 & 0.000 \\ \text { F6 } & 0.227 & 0.030 & 7.551 & 0.000\end{array}$

It should be noted that the model fit the data well: $\chi_{(181)}^{2}=618.078$, root mean square error of approximation $($ RMSEA $)=0.069$, standardized root mean square residual $($ SRMR $)=0.037$, Tucker-Lewis index $(T L I)=0.940$, and comparative fit index $(\mathrm{CFI})=0.948$. The coefficients representing the relationships specified in the model are shown in Figure 2.

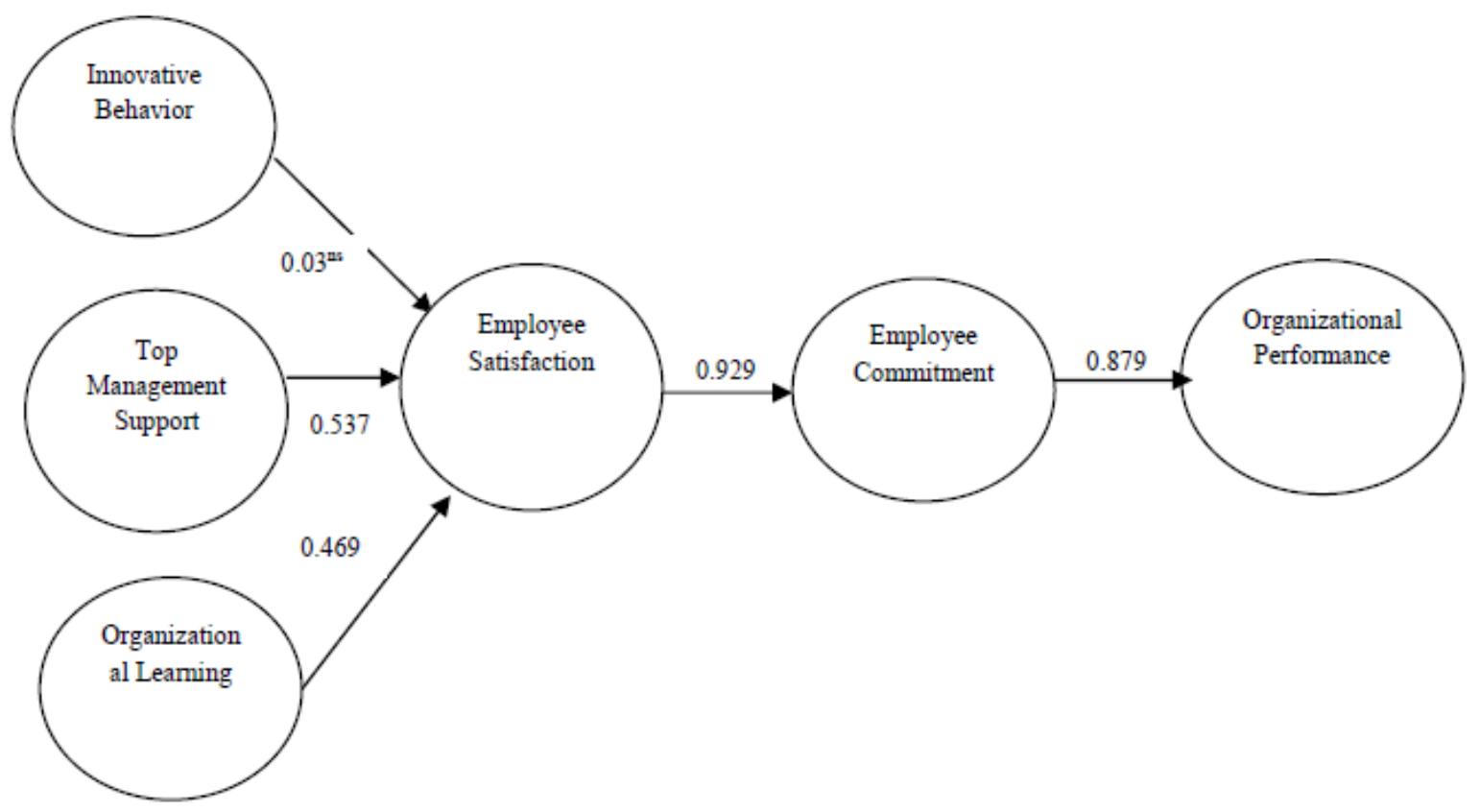

Figure 2. Results from testing the structural model

Table 7 summarizes the hypothesis test results. Such results are based on the parameter estimates, t-values, and signs of the parameter estimates. Based on these parameter estimates, $t$-values, and signs of the parameter estimates, four hypotheses were statistically supported by the data while Hypothesis 1 was not statistically supported by the data. The four hypotheses which were statistically supported by the data are TMS $\rightarrow$ ES; OL $\rightarrow$ ES; ES $\rightarrow$ EC; and EC $\rightarrow$ OP.

Table 7. Summary of the hypothesis test results

\begin{tabular}{llccc}
\hline Hypothesis & Causal path & $\begin{array}{c}\text { Path } \\
\text { coefficients }(\mathrm{\gamma})\end{array}$ & t-Value & $\begin{array}{c}\text { Hypothesis } \\
\text { supported }\end{array}$ \\
\hline $\mathrm{H} 1 \mathrm{IB} \rightarrow \mathrm{ES}$ & 0.03 & $0.188^{\text {ns }}$ & No \\
\hline
\end{tabular}




\begin{tabular}{lllll}
\hline $\mathrm{H} 2$ & TMS $\rightarrow$ ES & 0.537 & $2.876^{* * *}$ & Yes \\
\hline H3 & OL $\rightarrow$ ES & 0.469 & $8.036^{* * *}$ & Yes \\
\hline H4 & ES $\rightarrow$ EC & 0.929 & $80.799^{* * *}$ & Yes \\
\hline H5 & EC $\rightarrow$ OP & 0.879 & $51.426^{* * *}$ & Yes \\
\hline
\end{tabular}

Legends: IB, innovative behavior; TMS, top management support; OL, organizational learning; ES, employee satisfaction; EC, employee commitment; OP, organizational performance.

ns: not significant.

${ }^{* * *}$ Significant at $\mathrm{p}<0.01$ level.

Specifically, employee satisfaction was significantly influenced by top management support $\left(\mathrm{\gamma}_{2}=0.537, p<0.01\right)$; employee satisfaction was significantly influenced by organizational learning $\left(\gamma_{3}=0.469, p<0.01\right)$; employee commitment was significantly influenced by employee satisfaction $\left(\mathrm{\gamma}_{4}=0.929, p<0.01\right)$; and organizational performance was significantly influenced by employee commitment $\left(\mathrm{\gamma}_{5}=0.879, p<0.01\right)$. Therefore, Hypotheses $\mathrm{H} 2, \mathrm{H} 3, \mathrm{H} 4$, and $\mathrm{H} 5$ are supported.

\section{Conclusion}

The factors discussed above that is organizational learning, top management support, innovative behavior, employee commitment, and organizational performance are the focus of this study. Exploration of these variables was based on a systematic examination of literature, a unique contribution toward elaborating upon the elements impacting organizational performance. We implemented an extensive review of the literature and initially adopted many of the scales validated in the literature. These pilot scales were reviewed by four managers who had been involved in strategy initiatives in their companies, and five academicians, whose expertise is in organizational behavior. Several revisions were made based on the experts' comments/feedback. A brief version of the survey instruments is provided in Appendix. As shown, the questionnaire consists of 21 items. Among the 21 items, 4 items are designed to measure Innovative Behavior; 3 items for Top Management Support; 5 items for Organizational Learning; 2 items for Employee Satisfaction; 4 items for Employee Commitment, and 3 items for Organizational Performance. In this survey, each survey respondent was asked to rate his or her perception of and experience on a seven-point Likert scale. Descriptive statistics, Pearson correlation, and reliabilities of the scales utilized to evaluate the relevant constructs are implemented. In addition, a confirmatory factor analysis (CFA) was implemented to further assess the measurement model. Such analysis was based on a covariance matrix derived from the indicators.

In this study, we attempted to identify a group of factors that would lead to organizational performance by companies in Hai Phong. In order to collect data from companies in Hai Phong, 600 questionnaires were sent out. Each company received 5 questionnaires. There were a total of 120 companies. Among 600 questionnaires sent out, 511 questionnaires were returned and usable, resulting in a response rate of $85.17 \%$. As much, this study is conducted at an individual unit of analysis. The sample was selected (who will be examined) based on the requirement of in-depth information, with this in mind the entire population of employees from companies in Hai Phong were surveyed. This study therefore applied a purposive non-probability sample, examining the entire sample available instead of a sample based on probability or random sampling. As previously mentioned, an important facet of quantitative research is that it should be generalizable to a wider population. To be able to generalize, the sample selected should be representative or typical of the population being examined. Particularly, the organizations selected need to be representative. Specifically, employee satisfaction was significantly influenced by top management support $\left(\mathrm{\gamma}_{2}=\right.$ $0.537, p<0.01)$; employee satisfaction was significantly influenced by organizational learning $\left(\mathrm{\gamma}_{3}=0.469, p<0.01\right)$; employee commitment was significantly influenced by employee satisfaction $\left(\mathrm{\gamma}_{4}=0.929, p<0.01\right)$; and organizational performance was significantly influenced by employee commitment $\left(\mathrm{\gamma}_{5}=0.879, p<0.01\right)$. Therefore, Hypotheses H2, H3, H4, and $\mathrm{H} 5$ are supported.

\section{References}

Agarwal, S. (2000). Influence of formalization on role stress, organizational commitment, and work alienation of salespersons: A cross-national comparative study. Journal of International Business Studies, 35, 715-739

Baguma, P. (1992) Variables influencing organizational Commitment in Public Service, A research project funded by OSSREA. Department of Psychology, Makerere University.

Bakker, A. B., Killmer, C. H., Siegrist, J., \& Schaufeli, W. B. (2000). Effort-reward imbalance and burnout among nurses [Electronic version]. Journal of Advanced Nursing, 31, 884-891. 
Cox, H., \& Wood, J. R. (1980). Organizational structure and professional alienation: The case of public school teachers. Peabody Journal of Education, 50(1).

Dewe, P. J. (1993). Work stress and coping: Common pathways for future research? Work and Stress, 7, 1-3.

Dollard, M. F. (2002). Work Stress Theory and Interventions: From Evidenceto Policy A Case Study. Canberra City. The NOHSC Symposium on the OHS Implications of Stress. University of South Australia.

Dollard, M. F. (2003). Introduction: Context theories and intervention. In M.F. Dollard, A.H. Winefield, \& H.R. Winefield (Eds.), Occupational stress in the service professions. New York: Taylor \& Francis.

Dollard, M. F., Winefield, H. R., Winefield, A. H., \& De Jonge, J. (2000). Psychosocial job strain and productivity in human service workers: Atest of the demand- control support model. Journal of Occupational and Organizational Psychology, 73, 501-510.

Douglas, M. (2001). Queensland public sector - occupational stress intervention experience case study. Retrieved October 26, 2002.

Fox, S., \& Fallen, B. J. (2003). Modeling the effect work/life balance on job satisfaction and turnover intentions. Australian Journal of Psychology, 55,125-125.

Jex, S. M. (2002). Organizational Psychology: A Scientist Practitioner Approach. New York: John Wiley \& Sons.

Jones, F. I., \& Kinman, G. (2001). Approaches to studying stress. In F.I. Jones \& J. Bright (Eds), Stress: Myth, theory and research. Harlow, UK: Prentice Hall.

Kahn, R. L. (1986). On the conceptualization of stress. In A. Eichler, M. M. Silverman, \& D. M. Pratt (Eds.), How to define and research stress (pp. 41-43). Washington, DC: American Psychiatric Press, Inc.

Kahn, R. L., \& Cooper, C. L. (1993). Stress in the Dealing Room: High performers under pressure. Routledge: London and New York.

Mann, F. (1969). Toward an understanding of the leadership role in formal organizations. In R.Dubin (Ed.), Leadership and productivity. San Francisco, CA: Chandler.

Muller, B. H., \& Lee, J. (2002). Leader-member exchange and organizational communication satisfaction in multiple contexts. The Journal of Business Communication, 39(2), 220-244.

Nicholson, N. (2003). How to motivate your problem people. Harvard Business Review, 81(1), 56-66.

Osipow, S. H., \& Davis, A. (1988). The relationship of coping resources to occupational stress and strain. Journal of Vocational Behaviour, 32, 1-15. OSI Model Pacific Grove, California: Brooks/Cole Publishing Company.

Porter, L. W., Steers, R. M., \& Mowday, R. T. (2005). Do employee attitudes towards organizations matter? The study of employee commitment to organizations. In K. G. Smith \& M. A. Hill (Eds.), Great minds in management (pp. 171-189). New York: Oxford.

Simon, B. (1945). A reconstructed corpse., Magna Large, Charles Paris: 15 Long Preston, 302p; 23 c.

Turner, B., \& Chelladurai, P. (2005). Organizationaland occupational commitment, intention to leave, and perceivedperformance of intercollegiate coaches. Journal of Sport Management, 19(2), 193-211.

Wahn, J. (1998). Sex differences in the continuancecomponent of organizational commitment. Group \& Organizational Management, 23(3), 256-266.

Wiener, Y., \& Vardi, Y. (1982). Relationships between job, organization, and career commitments and work outcomes: An integrative approach. Organizational Behavior and Human Performance, 26, 81-96. 